\title{
FIIL MAZID DI DALAM AL QUR'AN \\ (STUDI MORFOLOGI BAHASA ARAB TERHADAP QUR'AN SURAT YASIN)
}

\author{
Miftahul Mufid, M.Pd.I \\ IAI Sunan Giri Bojonegoro, Indonesia \\ Email: miftahul.mufid@gmail.com
}

\begin{abstract}
:"language is something that is very important in life because without the language of communication will not occur. Language has a unique arrangement in each region. And the most interesting part of any language Arabic is written in the Qur'an because the book of Qur'an is a Book given by God to the Prophet Muhammad. other than that Qur'an is a miracle possessed by the prophet Muhammad. From here we as human beings are given intellect by God obligatory to study scripture. And the object of study This is the letter Yasin al-qur'an, while the focus of research is the scientific study of morphological / sharf namely in verb mazid in this letter. This study findings that in the letter contained Yasin Nineteen words that have a shape verb mazid".
\end{abstract}

Keywords: Morfologi, Sharf, Qur'an, Bahasa Arab

\section{PENDAHULUAN}

Secara bahasa Al Qur'an berasal dari bahasa Arab yang diambil dari kata قَرَك yang artinya 'membaca'. 1 Al Qur'an adalah kitab suci yang di turunkan oleh Allah kepada nabi Muhammad SAW yang di awali surat Al Fatihah dan di akhiri dengan surat Al Ikhlas. Al Qur'an merupakan mukjizat tidak ada satu orang pun di dunia ini yang mampu menandingi Al Qur'an baik dari segi bahasanya maupun isinya. Menurut Ali Ash Shabuni Al-Qur'an adalah kalam Allah SWT yang mengandung mukjizat yang diturunkan kepada Nabi Muhammad SAW dan Rasul dengan perantara malikat jibril. Dari sini kita dapat melihat bahwa Al Qur'an

\footnotetext{
${ }^{1}$ H.P Akhmad Yasin, Modul Pendidikan Islam. (2002. Semarang: Diponegoro Wilian).
} 
merupakan mukjizat yang paling istemewa di bandingkan dengan mukjizat lain yang dimiliki oleh nabi Muhammad SAW. Karena sampai saat ini mukjizat ini masih eksis dan masih terus di baca khususnya oleh umat Islam di seluruh dunia.

Al-qur'an mendorong kemajuan umat manusia baik dalam hal teknologi, sumber daya manusia dan juga akhlak. Al-qur'an sangat mengapresiasi orang yang melakukan penelitian dan orang yang berfikir. Al-qur'an menyebut dua tipe manusia ini dengan sebutan ulul albab. Menurut Fitria karena pentingnya kata ulul albab, di dalam Al-qur'an hingga di tulis sebanyak enam belas kali. Allah berfirman dalam surat shad ayat $29:$ كتب أنزلناه إليك مبارك ليدبرواياته وليتذكروا أولوالالباب. Yang artinya: "Ini adalah sebuah kitab yang kami turunkan kepadamu penuh dengan berkah supaya mereka memperhatikan ayat-ayatnya dan supaya mendapat pelajaran orang-orang yang mempunyai pikiran”. Tanda orang yang berpikir adalah orang yang selalu melakukan penelitian dan selalu mencari kebenaran. Tidak mudah terpengaruh dengan pendapat orang lain sebelum mendapat pengetahuan yang komperhensif dan menyeluruh merupakan tanda ulul albab.

Morfologi merupakan cabang yang terpenting dalam ilmu bahasa karena morfologi membahas bahasa dari bentuk katanya. Ilmu morfologi ini dalam bahasa arab di kenal dengan sebutan ilmu shorof. Ilmu shorof termasuk ilmu alat yang digunakan untuk mempelajari bahasa arab. Karena dengan ilmu ini kita dapat mengetahui perubahan bentuk sebuah kata, entah dia menjadi isim, fi'il, atau mungkin juga huruf.

Dari pentingnya Al-qur'an untuk di kaji dan di teliti, maka peneliti perlu memberi batasan mengenai penelitian ini. Peneliti tidak akan membahas seluruh al-qur'an akan tetapi hanya mengambil satu ayat dari Al-qur'an saja yakni surat yasin. Sedangkan yang akan di teliti adalah kata bentukan fi'il mazid dalam surat Yasin. Dan fokus kajian dari penelitian ini adalah

\section{PENGERTIAN MORFOLOGI}

Secara etimologi morfologi berasal dari kata morf yang berarti 'bentuk'dan kata logi yang berarti 'ilmu'. Jadi secara harfiah artinya 'ilmu 
mengenai bentuk'. Dalam kajian linguistik berarti 'ilmu yang mempelajari tentang pembentukan sebuah kata' ${ }^{2}$

Secara istilah morfologi menurut Abdullah Hasan adalah satu bidang ilmu yang mengkaji bentuk perkataan. ${ }^{3}$ Untuk mendapat pemahaman pengertian secara komperhensif mengenai morfologi bahasa Arab kita dapat mengutip pendapat dari Janet C.E. Watson penulis The Phonology and Morphology of Arabic dia mengatakan "Morphology deals with the way in which words are constructed. Morphology also accounts for morphological variation-that is, allomorphy. Within a phonological framework, morphology is important insofar as certain phonological rules are sensitive to morphological structure and are restricted to applying within specifi c derived morphological domains, while other phonological rules are insensitive to morphological structure. For example, coronal plosive voicing in San'ani requires no morphological specifi cation and applies whenever a coronal plosive occurs in intervocalic or word-initial position." Dilihat dari menurut pendapat diatas bahwa Morfologi adalah ilmu yang mempajari sebuah kata. Akan tetapi menurut Janet ilmu morfologi tidak terlepas dari ilmu fonologis. Walaupun diantara dua kajian ilmu ini mempunyai perbedaan, jika fonologi mempelajari tentang suara sedangkan morfologi mengkaji struktur kata.

Adapun kajian morfologi bahasa Arab di bahas dalam ilmu Sharf. Menurut Abdul Mu'in yang dinukil dari Al-Galayin Sharf adalah ilmu yang mempelajari tentang asal-usul sebuah kata dan dengan ilmu ini dapat diketahui bentuk-bentuk dari kata-kata bahasa arab dan keadaannya, yang bukan I'irab dan bukan bina' yaitu ilmu yang membahas tentang berbagai kata dari sisi tasrif, I'lal, idhgam, dan penggantian huruf. ${ }^{4}$

\footnotetext{
${ }^{2}$ Abdul Chaer, Morfologi Bahasa Indonesia (Pendekatan Proses), (2015, Jakarta: Rineka Cipta). H. 3

${ }^{3}$ Abdullah Hasan, Emeritus, Morfologi siri pengajaran bahasa Melayu, (2006, Selangor: PTSProfrssional) h.1

${ }^{4}$ Abdul Mu'in, Analisis Kontrastif Bahasa Arab Dan Bahasa Indonesia, (2004, Jakrta: Pustaka Al Husna Baru). H. 88
} 
Jika dilihat dari beberapa pengertian tentang morfologi maka dapat diambil sebuah kesimpulan bahwa pengertian morfologi menunjukkan perubahan sebuah kata sebelum disusun dalam suatu kaliamat, maksudnya adalah menyiapkan kata yang sesuai untuk di rangkaikan dalam suatu kalimat tertentu. Sedangkan yang kedua adalah morfologi adalah ilmu yang dipakai untuk meninjau sebuah proses terjadinya sebuah kata, atau istilah ini disebut dengan proses morfologis.

Menurut Samsuri proses morfologis adalah cara pembentukan kata-kata dengan menghubungkan morfem yang satu dengan yang lain. ${ }^{5}$ Dari pengertian ini dapat kita lihat 'kata' adalah bentuk minimal yang bebas, maksud dari bebas adalah bentuk itu dapat diucapkan tersendiri, dapat di dahului dan di ikuti oleh jeda potensial. Dengan begitu dapat kita amati bahawa bentuk terkecil sebuah bahasa adalah morfem dan yang terbesar adalah kata.

\section{PENGERTIAN KATA}

Menurut Rini Damayanti dia memberi definisi kata sebagai kumpulan beberapa huruf yang memiliki makna tertentu. ${ }^{6}$ Sedangkan menurut kamus besar bahasa Indonesia (KBBI) kata adalah unsur bahasa yang diucapkan atau dituliskan yang merupakan perwujudan suatu perasaan dan pikiran yang dapat dipakai dalam berbahasa.

\section{Pengertian Dan Pembagian Fi'il mazid}

Untuk mendapatkan pengertian fi'il mazid secara komperhensif kita bisa melihat pedapat imaduddin menurut dia fi'il mazid adalah fi'il yang huruf aslinya

\footnotetext{
${ }^{5}$ Samsuri, Analisis bahasa memahami bahasa secara ilmiah,(1987, Jakarta: Erlangga). H. 190

${ }^{6}$ Rini Damayanti dan Tri Indriyanti, Bahasa Indonesia Untuk Perguruan Tinggi,(2015, Jakarta:

Victory Inti Cipta). H. 75
} 
an. Dalam pembagiannya fi'il mazid terbagi menjadi dua an ruba'I mazid. ${ }^{7}$

Fi'il Tsulasi Mazid yang bertambah satu huruf( ثلاث مزيد بحرف

Adapun fi'il tsulasi mazid yang bertambah satu huruf ini terbagi menjadi tiga bab:

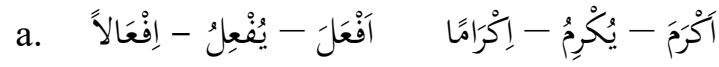

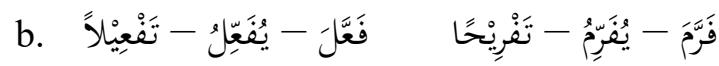

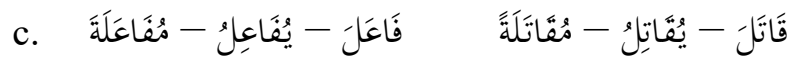

1. Fi'il Tsulasi Mazid yang bertambah dua huruf (ثلاث مزيد بحرفين)

Fi'il tsulasi mazid yang bertambah dua huruf ( حُمَاسى ) ini terdiri atas lima bab yaitu:
a. إمْفَعَل - يَنْفَعِلُ - إنْفِعَالاً
إنْكَسَرَ - يَنْكَسِر - إنْكِسَارًا

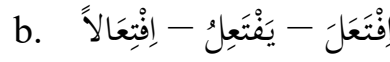
إاجْتَمَعْ - يَجْتَمَعُع - إِجْتِمَاعًا

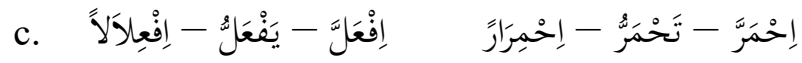
d. تَخكَلَّمَ - يَتَكَلَّمُ - تَكَكُلُمَّا

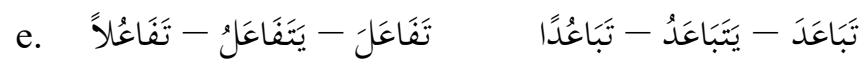

2. Fi’il Tsulasi Mazid yang bertambah tiga huruf ( ثلاث مزيد بثلاثة )

Fi’il tsulasi mazid yang bertambah tiga huruf ( ثلاثى مزيد بِثَلأَفِة احَرُرِفِ Terdiri atas 4 bab:

\footnotetext{
${ }^{7}$ Imaduddin Sukamto \& Akhmad Munawari, Tata Bahasa Arab Sistematis, (2008, Yogyakarta: Nurma Media Idea). H. 26

${ }^{8}$ Ma'sum Ali, Al Amtsilah Al Tashrifiyah,(1997, Kediri: Maktabah Alawiyah). H. 8
} 


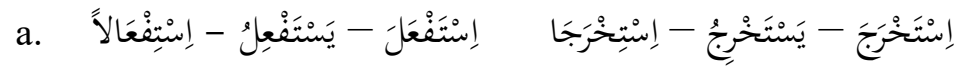

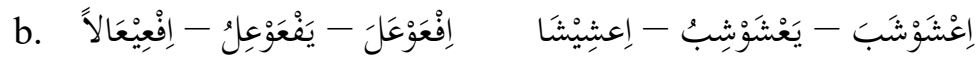
c. إِجْلَوَّذَ - تَجْلَوَذُْ - إِجْلِوَاذًا

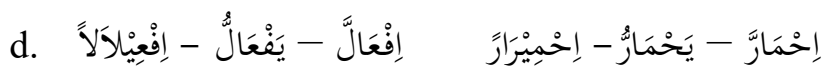

\section{Makna wazan fi'il mazid}

Ketika kita membandingkan morfologi bahasa arab dan bahasa Indonesia. Diantara keduanya memiliki kesamaan diantaranya. Persamaan diantara keduanya adalah Ada kata mendapat imbuhan, dan imbuhan ini bisa merubah arti kata tersebut. Akan tetapi dalam penelitian ini, kami hanya batasi makna wazan tidak pada semua fi'il mazid akan tetapi hanya makna wazan yang ada di dalam surat Yasin.

A. Makna wazan fa'-'ala (فَسَّeَ)

1. Li ta'diyah /memuta'addikan fi'il lazim.

Contoh:

فَسََّح زيد عمرا

"Zaid menggembirakan 'Amar". (bentuk asal fi' 'il lazim FAROHA = gembira)

2. Li Taktsir/menunjukkan memperbanyak.

Contoh :li

قطع زيد الحبل

"Zaid memotong-motong tali"

(menjadiakannya banyak potongan. Bentuk asal $f i^{\prime} i l$

QOTHO'A=memotong 1 potongan)

3. Lin-Nisbah /menisbatkan maf'uul (objek) pada bentuk asal fi' $i l$.

Contoh: 
"Zaid mengkafirkan 'Amar”

(menisbatkannya pada bentuk asal fi'il KAFARO=kafir)

4. Li Salbi /membuang bentuk asal fi'il dari objeknya (maf'ulnya)

Contoh:

قشر زيد الرمان

"zaid menguliti buah delima"

(yakni membuang kulitnya, bentuk asal $f i$ 'il QOSYIRO=berkulit)

5. Li Ittikhad Lil-Fi'li Minal-Ismi /menjadikan fi'il dari isim.

Contoh:

خيم القوم

"Kaum itu berkemah"

(yakni, mereka mendirikan dan tinggal di kemah, asal bentuknya kalimah isim yaitu KHIYAAM=kemah)

B. Makna wazan ISTAF'ALA ( اسْتَفْعَل )

1. Fa'il meminta maf'ul melakukan suatu pekerjaan.

Contoh: أَنَتَغْفِرُ اللهَ (saya memohon ampun kepada Allah) berarti saya meminta Allah mengampuni saya.

2. Menemukan suatu sifat yang dimiliki oleh maf'ul.

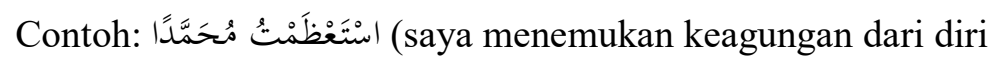
muhammad)

3. Perubahan keadaan fa'il kepada asal fi' $i l$.

Contoh: اسنتَحْجَرَ الطِّيّنْ ( tanah ini membatu)

4. Takalluf, maksudnya pelaku berusaha lebih untuk menampakkan sesuatu dari dalam dirinya.

Contoh: اسْتَجْرَأَ مُحَََّدُد (Muhammad memberanikan diri) 
5. Makna فَعَل Mujarrod

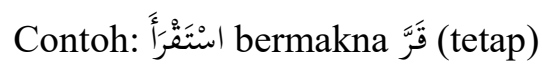

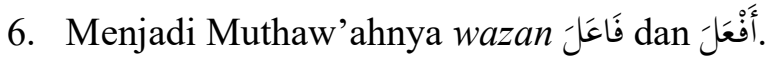

Contoh: أَحْكَمْنُعُ, فَسْتَحْكَمَ (saya telah mengukuhkannya, maka jadilah kukuh.)

C. Makna wazan Af’ala أفعل (tambahan hamzah qotho' awal kalimah)

1. Li ta'diyah (memuta'addikan fi'il lazim), contoh:

أكرمت زيدا

aku menghormati zaid.

2. Lid-Dukhuuli Fisy-Syai' (masuk pada sesuatu), contoh:

أمسى المسافر

Musafir itu/seorang yg dalam perjalanan itu sudah masuk sore.

3. Li Qashdil-Makaan (hendak ke suatu tempat), contoh:

أحجز زيد

Zaid hendak ke Hijaz

أعرق زيد

Zaid hendak ke Iraq

4. Li Wujuudi Maa Usytuqqa Minhu Al-Fi'lu Fil-Faa'il (untuk menunjukkan adanya suatu barang pada Fa'il, yg mana fi'ilnya dimusytaq dari nama berang tsb, contoh:

أثمر الطلح

pohon itu telah berbuah

أورق الشجر

pohon itu telah berdaun

43 Volume 1, Nomor 1, Februari 2017 
5. Lil Mubaalaghoh (mempersangat/melebihkan), contoh:

أشغلت عمرا

'Amar, yakni aku menjadikannya lebih sibuk.

6. Li Wijdaani Sy-Syai' Fi Sifatin (merasakan adanya sesuatu di dalam suatu sifat), contoh:

أعظمت زيدا

aku mendapati zaid seorang yg agung.

أحمدت زيدا

aku mendapati zaid seorang yg terpuji.

7. Lish-Shairuurah (menjadi), contoh:

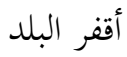

Negeri itu menjadi gersang

8. Lit-Ta'riidh (menampakkan/memajang), contoh:

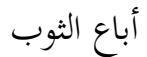

aku memajang baju untuk dijual.

sekitar sejam yang lalu

9. Lis-Salbi (menanggalkan), contoh:

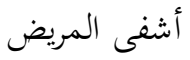

orang sakit itu telah hilang kesembuhannya

10. Lil-Hainuunah (tiba masanya), contoh:

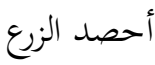

tanaman itu sudah waktunya panen

D. Makna wazan TAFA"ALA تفعّل

44 Volume 1, Nomor 1, Februari 2017 
Menambah huruf TA' di awal kalimah dan mendobelkan Ain Fi' il

1. Li Muthawa'ah "Fa"ala" (sebagai Muthowa'ah dari fi'il wazan "Fa"ala) Muthowa'ah adalah peristiwa terjadi oleh sebab pekerjaan Fi'il Muta'addi, contoh:<smiles>C=[As][As]=[As][As]</smiles>

aku memecahkan kaca, maka kaca menjadi pecah.

2. Lit-Takalluf(berdaya upaya dalam pekerjaan untuk menghasilkan), contoh:

تَشَجَجَعَ زَيْدُ

Zaid memberanikan diri.

3. Li ittikhaadil-faa'il ashlal-fi'li maf'uulan (menjadikan asal bentuk Fi'il sebagai Maf'ul), contoh:

تَبَنَبَّنتُ يُوْسُفنَ

aku mengambil Yusuf sebagai anak.

4. Lid-dalaalati 'alaa mujaanabatil-fi'li (untuk menunjukkan keengganan), contoh:

تَذََََّمَ زَيْدُ

Zaid menghindari celaan.

5. Lis-Shoiruuroh (menjadi),contoh:

تَأَيَّمَتْ المَنْأَتُ

perempuan itu menjadi janda.

6. Lid-dalaalati 'alaa hushuuli ashlil-fi'li marrotan ba'da ukhroo (menunjukkan pekerjaan terjadi satu demi satu), contoh:

تَجَرََّع زَيْدُ

Zaid minum seteguk demi seteguk.

7. Lit-Tolab (mengharap), contoh:

تَعَجَّلَ الشَّيَْْ

45 Volume 1, Nomor 1, Februari 2017 
dia mengharap sesuatu dg segera

dia mengharap kejelasan sesuatu.

\section{METODE PENELITIAN}

Metode penelitian yang di gunakan dalam penelitian ini adalah penelitian kualitatif dengan menekaknkan analisis isi. Metode kualitatif adalah metode penelitian yang digunakan untuk meneliti kondisi objek yang alamiah. Dalam penelitian ini peneliti menjadi isntrumen kunci, dalam pengumpulan datanya menggunakan teknik trianggulasi, analysis data bersifat induktif. Sedangkan objek dari penelitin adalah Al Qur'an Al Karim akan tetapi tidak seluruh dari surat Al Qur'an menjadi focus dari penelitian ini. Peneliti hanya memfokuskan penelitian ini pada satu surat saja yakni surat Yasin yakni dari ayat satu sampai ayat terakhir.

Dalam penelitian ini peneliti menggunakan metode kualitatif dan dalam analisisnya peneliti menggunakan analisis isi atau konten. Prosedur penelitian yang digunakan adalah sebagai berikut: (a) pemrosesan teks secara sistematis menggunakan teori yang telah dirancang. (b) teks tersebut dicari unit-unit analysis dan di kategorikan sesuai acuan teori. (c) mensinkronkan antara proses analisis dan pemahaman teori. (d) proses analisis mendasarkan pada deskripsi, (e) analisis dilakukan secara kualitatif. 9

ANALISIS ISI KALIMAT FI'IL MAZID DALAM SURAT YASIN

kami mengutus ارسلنا

\begin{tabular}{|c|c|c|}
\hline إِرْسَْْ & يُرْبسشُ & اَرَسََْلَ \\
\hline إفْعََْ & يُفْعِلُ & اَفْْعَلَ \\
\hline
\end{tabular}

\footnotetext{
${ }^{9}$ Suwardi Endraswara, Metodologi Penelitian Sastra epistimologi, model,teori, dan aplikasi,(2003, Yogyakarta: CAPS). H. 162
}

46 Volume 1, Nomor 1, Februari 2017 


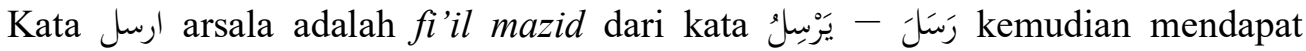
tambahan 1 huruf di depan yakni hamzah. Kata arsala termasuk kategori Fi'il Tsulasi Mazid yang bertambah satu huruf. Adapun makna atau faedah dari wazan arsala adalah li ta'diyah yakni memutaadikankan fi'il lazim.

\section{kami sial/celaka . .}

\begin{tabular}{|c|c|c|}
\hline تَطَيَّْ & يَتَطيََرَ & تَطيَّرَ \\
\hline تَفَعَعَّلْ & يَتَفَعَّلَ & تَفَعَّلَ \\
\hline
\end{tabular}

Kata تطيرنا termasuk fi'il mazid karena mempunyai dua huruf tambahan dan fi'il mazid ini termasuk dalam kategori tsulasi mazid khumasi. Sedangkan makna wazan kata ini adalah li ta'diyah.

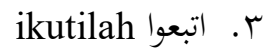

\begin{tabular}{|c|c|c|}
\hline+2 & يَتَبَعُ & الِتَبَعَع \\
\hline اِتتَتَبْغ & يَتْتَبَعُ & الِتْتَبَعَع \\
\hline إِفتَعِعلْ & يَفْتَعِلُ & إفْتَعَعَل \\
\hline
\end{tabular}

Kata إنَّبَعَ merupakan fi 'il mazid karena mendapat hruf tambahan kata dasar dari kata ini adalah تَبَعَ- يَتْبَعُ. Kata ini merupakah fi'il tsulastsi mazid dengan imbuhan dua huruf, yaitu hamzah washol di awalnya dan terdapat huruf ta' diantara fa' fi'il dan 'ain fi'ilnya. Sedangkan makna wazan إنَّبَع adalah لمعنى المجرد (semakna dengan bentuk mujarodnya).

$$
\text { ع ع. انزلنا kami menurunkan }
$$

\begin{tabular}{|c|c|c|}
\hline اَنْْزْ & يُنْنِلُ & اَنْزَلَ \\
\hline
\end{tabular}




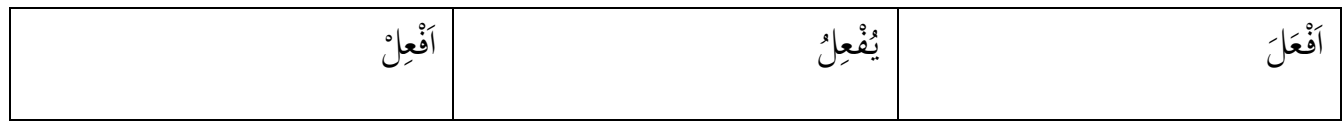

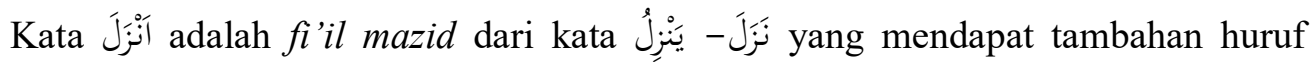

twal katanya. Kata اَنََْْ mempunyai makna wazan li ta'diyah yakni berfungsi unntuk memutaadikankan fi'il lazim.

kami telah binasakan

\begin{tabular}{|c|c|c|}
\hline آَهْلِكْ & يُهْهِكُ & اَهْلَكَكَ \\
\hline اََفْعِلْ & يُفْعِلُ & اَفْعَلَ \\
\hline
\end{tabular}

Kata اهلك اهلك-يهلك هatah adah fi'il mazid dari kata mendapat tambahan huruf hamzah qath' pada awal katanya. Kata اهلك mempunyai makna wazan li ta'diyah yakni berfungsi unntuk memutaadikankan fi'il lazim.

kami hidupkannya 7

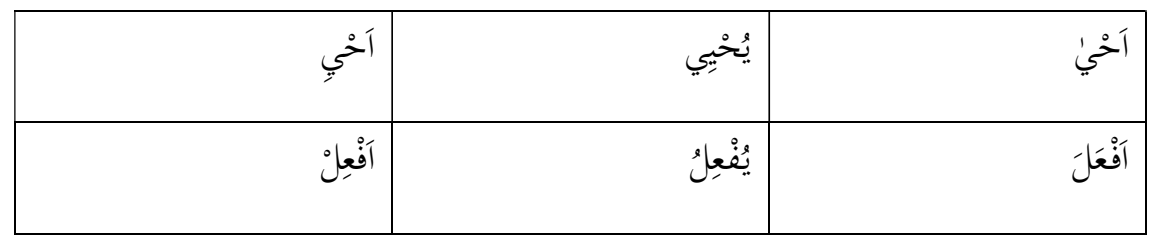

Kata احيينها حَيَّ-يُخْي yang mendapat tambahan huruf hamzah pada awal katanya. Kata ini mempunyai makna li ta'diyah yakni berfungsi untuk memutaadikankan fi'il lazim.

$$
\text { dan kami keluarkan واخرجن V }
$$

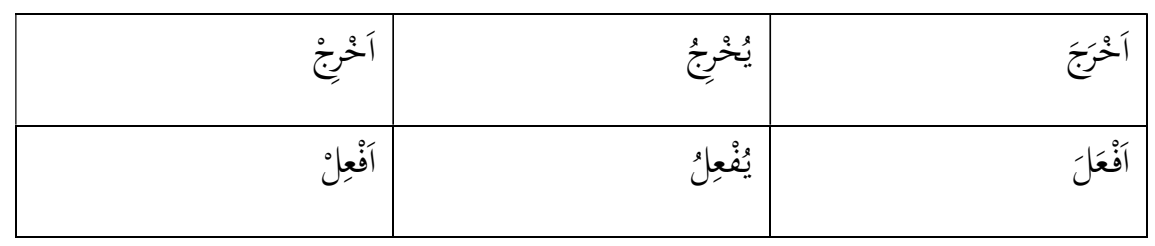


Kata اخرج adalah fi'il mazid dari kata dasar خرج yang artinya keluar. Kemudian mendapat imbuhan hamzah pada awal katanya kemudian menjadi اخرج yang artinya mengeluarkan. Kata mempunyai makna wazan li ta'diyah.

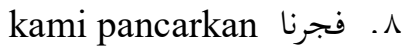

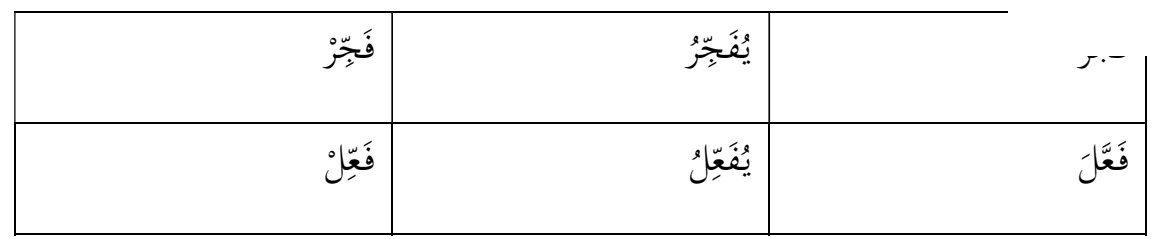

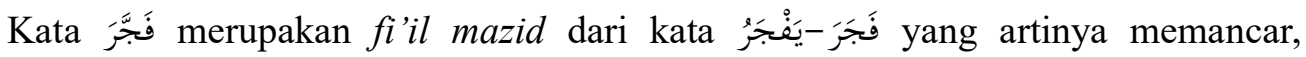
فemudian mendapat tambahan huruf yang sama pada ain fi'ilnya menjadi فَجَّرَ yang Berubah menjadi memancarkan. Kata فَجَجَرَ mempunyai makna wazan li ta'diyah.

kita mentakdirkan ق و 9

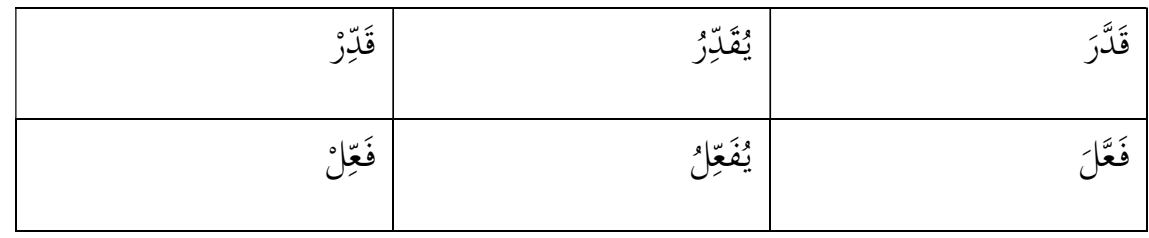

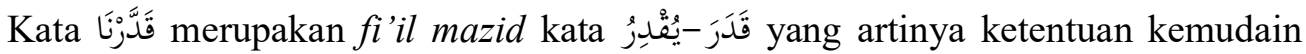

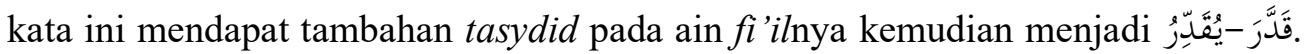
Adapun makna wazan dari kata ini adalah li ta'diyah.

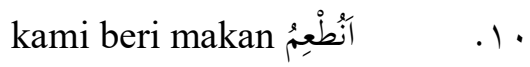

\begin{tabular}{|c|c|c|}
\hline آَطْعِمْ & يُطْعِمُ & اََطْعَمَ \\
\hline اَفْعِنْ & يُفْعِلُ & اََفْعَلَ \\
\hline
\end{tabular}


Kata انطعم merupakan fi'il mudhori' ikut wazan انفل makan fi'il mazid dari kata dasar طَع yeng artinya merasakan. Kemudian mendapat tambahan huruf hamzah di awal kalimat. Sedangkan makna wazan dari kata ini adalah li ta'diyah. mereka bertengkar 11

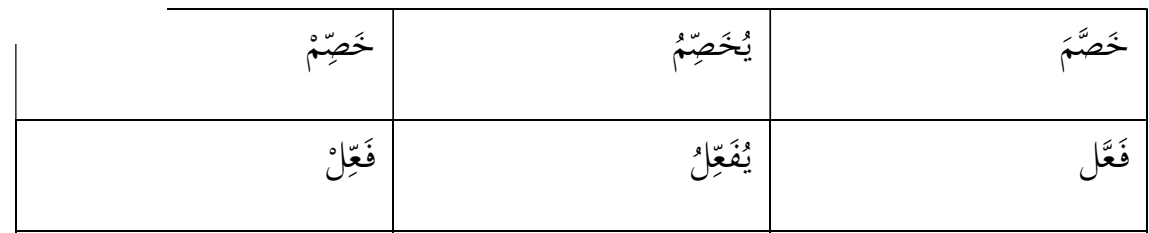

Kata يخصم merupakan fi'il mazid dari kata خَصَمَ-َيِْْصُ yang berarti melawan kemudian mendapat tambahan tasydid pada ain fi'ilnya kemudian menjadi yang berarti . Sedangkan makna wazan dari kata ini adalah li ta'diyah. ia telah menyesatkan

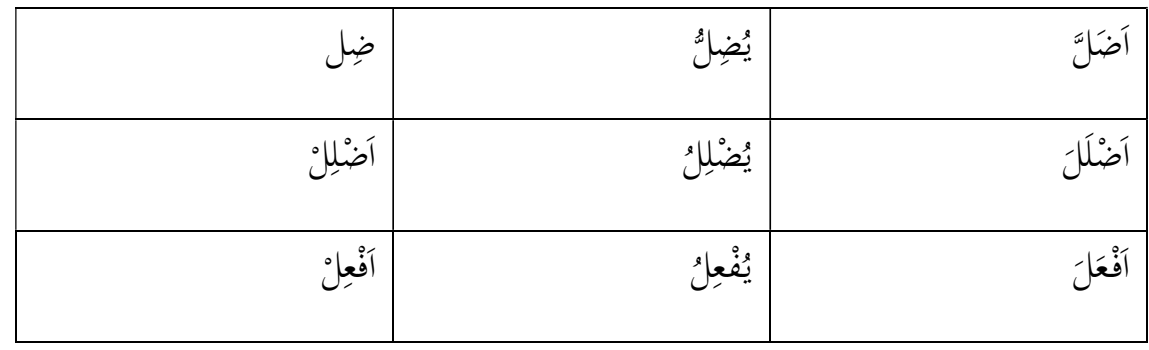

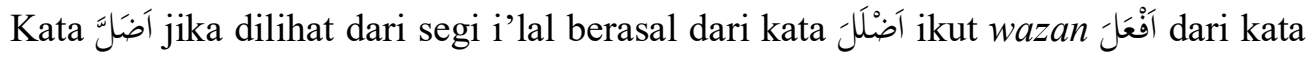
dasar ضَلَّ-َيَضِلُ yang artinya telah tersesat. Kemudian mendapat huruf hamzah di awal katanya. Sedangkan makna dari wazan ini adalah li ta'diyah.

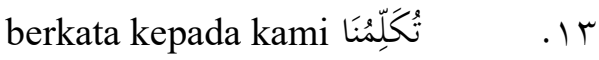

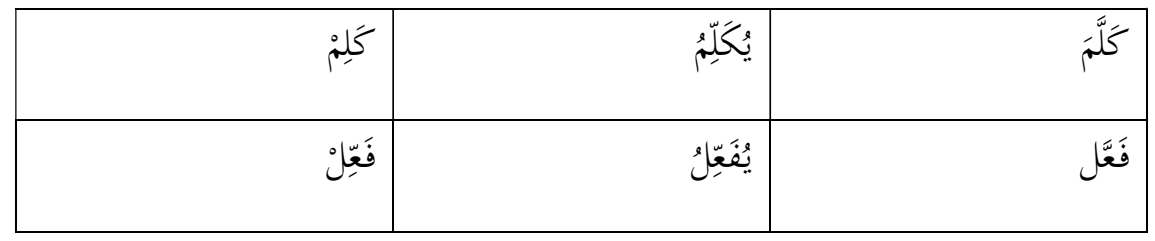


Kata تُكَلِّمَنَ merupakan fi'il mazid dari kata كلم yang artinya berbicara, kemudian mendapat tambahan tasydid pada 'ain fi'ilnya kemudian menjadi Adapun makna wazan dari kata ini adalah li ta'diyah.

mereka berlomba-lomba فاستبقوا

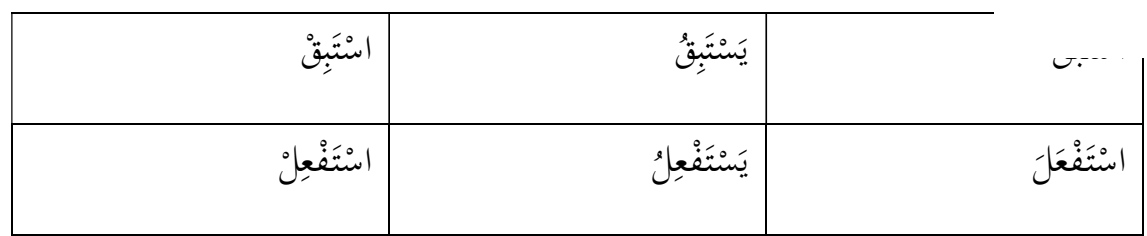

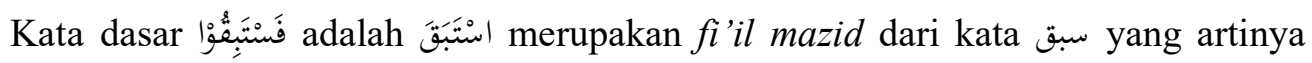
lebih dulu, kemudian mendapat tambahan hamzah diawal kalimat menjadi استبق. Adapun makna wazan dari kalimat ini adalah li ta'diyah.

Kami panjangkan 10

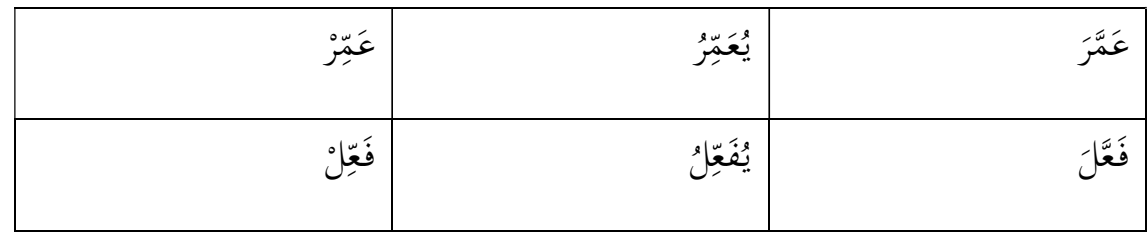

Kata عَمَّ merupakan fi'il mazid dari kataَعَ yang artinya menghuni, kemudian mendapat tambahan tasydid pada ain fi'ilnya. Adapun makna wazan dari kata berikut adalah li ta'diyah.

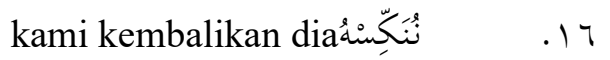

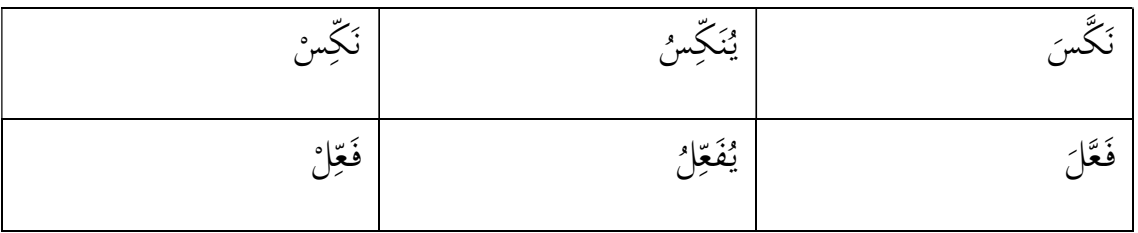

Kata نَكََّّ merupakan fi il mazid dari kata نَكَ yang artinya mebalikkan kemudian mendapat tambahan tasydid pada ain fi'ilnya. Dan memiliki makna wazan li ta'diyah. 


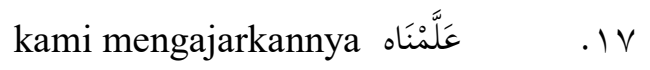

\begin{tabular}{|c|c|c|}
\hline عَلِّمْ ع & يُعَعِلِّم & عَلَّمَ \\
\hline فَعِّلْ & يُفَغَِلُ & فَعَّلَ \\
\hline
\end{tabular}

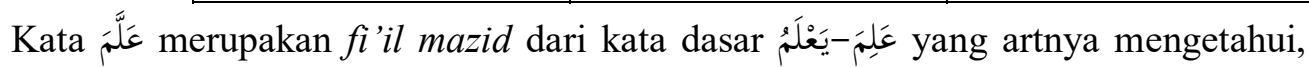

$\mathrm{t}$ tambahan tasydid pada ain fi'ilnya, adapun makna wazan dari kata ini adalah li ta'diyah.

dan kami tundukkannya وَذَذَلَّنَاَْا

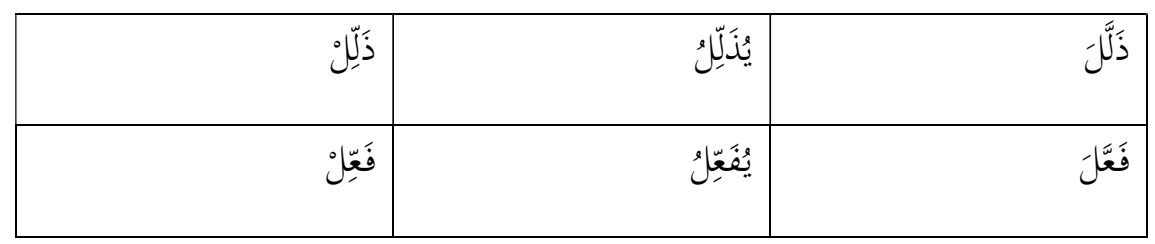

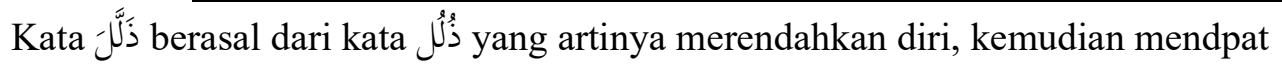
tambahan syakal tasydid pada ain fi'ilnya. Adapun makna wazan dari kata ini adalah li ta'diyah.

\section{KESIMPULAN}

Dalam surat yasin terdapat lima bentuk wazan fi'il mazid diantaranya wazan تَفَعَّلَ dan Dengan perincian sebagai berikut : wazan

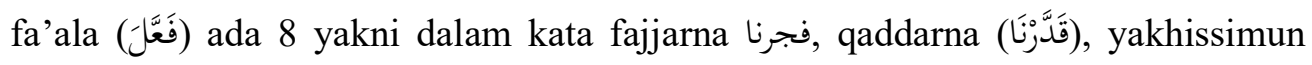

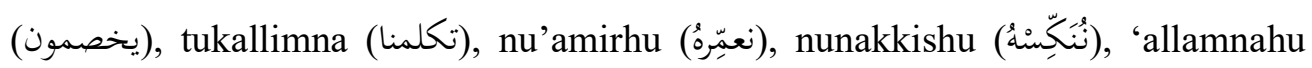

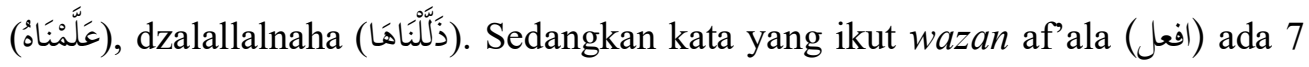

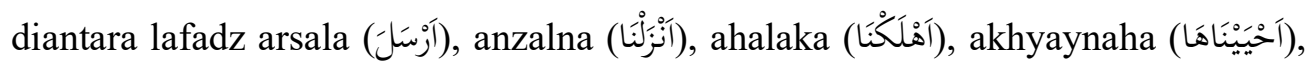

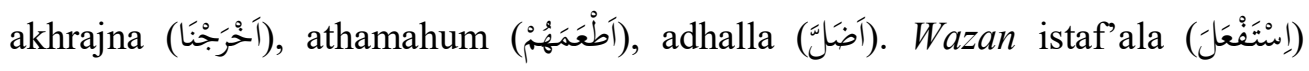

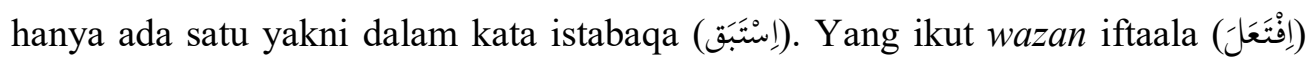


hanya ada satu yakni dalam kata ittabi’u (التَّبعُوْاُ(). Sedangkan yang ikut wazan tafa'ala (تَفَعَّلَ) yakni dalam kata tathayyarna (تَطَيَّنْنَا).

\section{Daftar pustaka}

\section{Rineka Cipta.}

Abdullah Hasan, Emeritus, 2006, Morfologi siri pengajaran bahasa Melayu, Selangor: PTSProfrssional.

Abdul Mu'in, 2004, Analisis Kontrastif Bahasa Arab Dan Bahasa Indonesia, Jakarta: Pustaka Al Husna Baru.

Samsuri, 1987, Analisis bahasa memahami bahasa secara ilmiah, Jakarta: Erlangga.

Rini Damayanti dan Tri Indriyanti, 2015, Bahasa Indonesia Untuk Perguruan Tinggi, Jakarta: Victory Inti Cipta.

Imaduddin Sukamto \& Akhmad Munawari, 2008, Tata Bahasa Arab Sistematis, Yogyakarta: Nurma Media Idea.

Ma'sum Ali, 1997, Al Amtsilah Al Tashrifiyah, Kediri: Maktabah Alawiyah.

Suwardi Endraswara, ,2003, Metodologi Penelitian Sastra epistimologi, model,teori, dan aplikasi. Yogyakarta: CAPS. 